\title{
The vitamin $D$ activity of pastures and hays
}

\author{
By KATHLEEN M. HENRY, S. K. KON AND S. Y. THOMPSON \\ National Institute for Research in Dairying, Shinfield, Reading \\ AND JENNIE W. MCCALLUM AND THE LATE J. STEWART \\ Moredun Institute, Gilmerton, Edinburgh 9 \\ (Received 4 Fune I 958-Revised I 5 Fuly 1958)
}

There is not much information about the vitamin D content of fodders and hay. Most of it is from the United States and, more recently, Holland. Keener (I 954) and Weits (1956) have summarized the available information. No such assessments apparently having been made in this country, an opportunity was taken to make a systematic study of the vitamin D activity of Scottish hill pastures. Monthly samples were obtained from one pasture during the sheep-grazing period in 3 consecutive years, and the vitamin $D$ activity of the grass fat was determined. While this investigation was in progress experiments were begun at Shinfield to compare the nutrient content of hay made by the orthodox use of the pick-up baler (ground-cured) or on tripods with that of the original sward (Murdoch, Foot, Hosking, Line \& Rowland, 1959; Thompson, 1959). Vitamin D assays were done on some of the samples and the results are also reported here.

\section{EXPERIMENTAL}

\section{Collection and drying of samples}

Scottish hill pastures. Samples were obtained at Netherphawhope from a hillside plot permanently surrounded with wire netting to keep off sheep. A representative sample was cut, with sheep-shearing shears, once a month from May to November in 1952 and from April to November in 1953 and 1954. Samples were brought straight back to the laboratory, spread on paper on a floor and stirred and turned periodically for 3 or 4 days until dry enough to mill. Fat was extracted from the dried samples as described below; the non-saponifiable residue was stored at about $3^{\circ}$ until rats were available for the biological assays, when it was dissolved for dosing in a suitable weight of arachis oil.

Shinfield pastures and hays. The making and sampling of the different hays are described in detail by Murdoch et al. (1959). For convenience relevant information about the hays is summarized in Table $3 B$. The dry herbages were stored in sealed tins at $3^{\circ}$ until rats were available for biological tests and were then extracted and dissolved for dosing as described below.

\section{Methods of extraction}

Originally the air-dried samples were extracted directly with light petroleum. During the course of the experiments, however, Weits (1953a) reported that this method usually did not remove all the vitamin $\mathrm{D}$ activity from samples and that more 
could be obtained by a similar extraction after saponification of the residue from the first extraction. This double-extraction procedure was adopted for a time; later the preliminary extraction was omitted, and the air-dried samples were saponified before solvent extraction.

Extraction of vitamin $D$ from dried herbage by high-boiling light petroleum. The method used follows closely that of Nelson (1947) and as described applies to $100 \mathrm{~g}$ of finely ground material. The sample is steeped overnight at room temperature in $500 \mathrm{ml}$. light petroleum (b.p. $80-100^{\circ}$ ) and the mixture is then boiled for $4 \mathrm{~h}$ under reflux with a water-cooled condenser. The residue, after decantation, is washed with $500 \mathrm{ml}$. light petroleum. The light-petroleum extracts are filtered through a Whatman no. 4 filter-paper on a Buchner funnel.

The solvent is evaporated and the fat residue weighed. The fat is then saponified and the non-saponifiable residue extracted as described by Kon \& Thompson (1957). After weighing, the non-saponifiable residue is dissolved in a quantity of arachis oil suitable for biological assay.

Extraction of vitamin D by saponification of dried herbage or of the residue left after light-petroleum extraction. This method is essentially as described to us by Weits $(1953 a)$. The finely milled material ( $100 \mathrm{~g})$ is heated under reflux for $30 \mathrm{~min}$ with $500 \mathrm{ml}$. ethanol, $60 \mathrm{~g} \mathrm{KOH}$ and $30 \mathrm{ml}$. water. After cooling, the mixture is filtered through two thicknesses of Whatman no. 54 paper on a Buchner funnel. The residue on the filter-paper is washed with $800 \mathrm{ml}$. light petroleum (b.p. $40-60^{\circ}$ ), which solvent is used for the first extraction of the filtrate diluted with $460 \mathrm{ml}$. water. A second extraction with $800 \mathrm{ml}$. of this light petroleum follows. The combined solvent extracts are washed once with $500 \mathrm{ml}$. distilled water, dried over anhydrous sodium sulphate and evaporated; the non-saponifiable residue is weighed and dissolved in arachis oil.

\section{Biological assay}

The vitamin D activities of extracts of pastures and hays were determined prophylactically on rats as described by Henry \& Thompson (1954). All experiments lasted for 4 weeks and groups of six to twelve litter-mate rats were used. The standard preparation of vitamin D was given at two to four levels and the test solutions at two levels. It was impossible to predict accurately the potency of the various samples of herbage and it was not always possible to carry out repeat tests with the Scottish hill pastures, as a sufficiently large sample could not be initially obtained from the plot to allow for replication. With the Shinfield samples a preliminary assay was usually done to estimate the order of potency.

Scottish hill pastures. The initial assays of the samples collected in 1952 were done with groups of twelve rats; repeat tests with the May and June samples were done with groups of six rats and of the July sample with groups of ten rats. There was not enough of the September and November samples to repeat the tests. From all samples vitamin D was extracted with light petroleum. Groups of eight rats were used in all assays on the 1953 and 1954 samples. Tests were done on light-petroleum extracts of all samples; in addition the potency of extracts of the saponified residue (see above) was determined in the samples for September and November 1953 and in 
all the 1954 ones. There was not enough of the October 1953 and the November 1953 and 1954 samples to repeat these assays, and it was only possible to repeat tests with the April to July 1954 samples by doing a combined assay for April-May and for June-July.

Shinfield pastures and hays. In 1954 only light-petroleum extracts of the pasture and of the two hays (ground-cured and tripod) were assayed. Assays of the 1955 pasture and hays were done on light-petroleum extracts of $(a)$ the original sample, $(b)$ the saponified residue from $(a)$, and $(c)$ the original sample after saponification. In 1956 only the last procedure was used to prepare the samples for test. To test further the adequacy of these extraction procedures assays were done on three extracts, prepared as with the 1955 samples, of an additional sample of hay cured in I956 (the 'special' hay in Table 2). This hay, made earlier in the season than the experimental hays for that year, had lain on the ground for a considerable time after cutting but weather conditions were not recorded. For this particular test a sample with high vitamin $\mathrm{D}$ was desirable and this 'special' hay proved suitable for the purpose.

\section{RESULTS}

\section{Scottish hill pastures}

The results of tests done in 3 consecutive years are given in Table $\mathrm{I}$. The vitamin D activity of the samples differed markedly and there was no consistent trend over the different years. These results also show that direct extraction of the sample leaves variable, and sometimes considerable, amounts of the vitamin in the residue.

\section{Shinfield pastures and hays}

The results are shown in Tables 2 and 3 . Table 2 compares the different methods of extracting vitamin $\mathrm{D}$ from the samples, confirming the results obtained for the Scottish hill pastures that all the vitamin $D$ activity of herbage is not extracted directly with light petroleum. Table 2 also shows that, within the limits of error of such tests, most of the activity can be extracted if the samples are saponified before extraction; for routine assays this procedure is less laborious and more sparing of solvents than the double-extraction procedure recommended by Weits (1956).

Table 3 gives the results for the Shinfield pastures and hays assayed in 3 consecutive years. Although the 1954 values are minimum estimates, because only the directextraction procedure was used, they are all considerably higher than the 1955 and I $95^{6}$ values obtained after solvent extraction of the saponified samples. In each of the three seasons the hays were much more active than the original sward and the groundcured hays more potent than the tripod ones. In tripoding only the outer layers are subject to appreciable radiation. No explanation can be offered for the high vitamin D activity of the original sward in 1954; the maturity of the pasture was similar in 1954 and 1955 but somewhat less in 1956 . The absolute increase in activity during curing was related to the amount of sunshine to which the hays had been exposed (cf. Table 3). 
Vol. I2

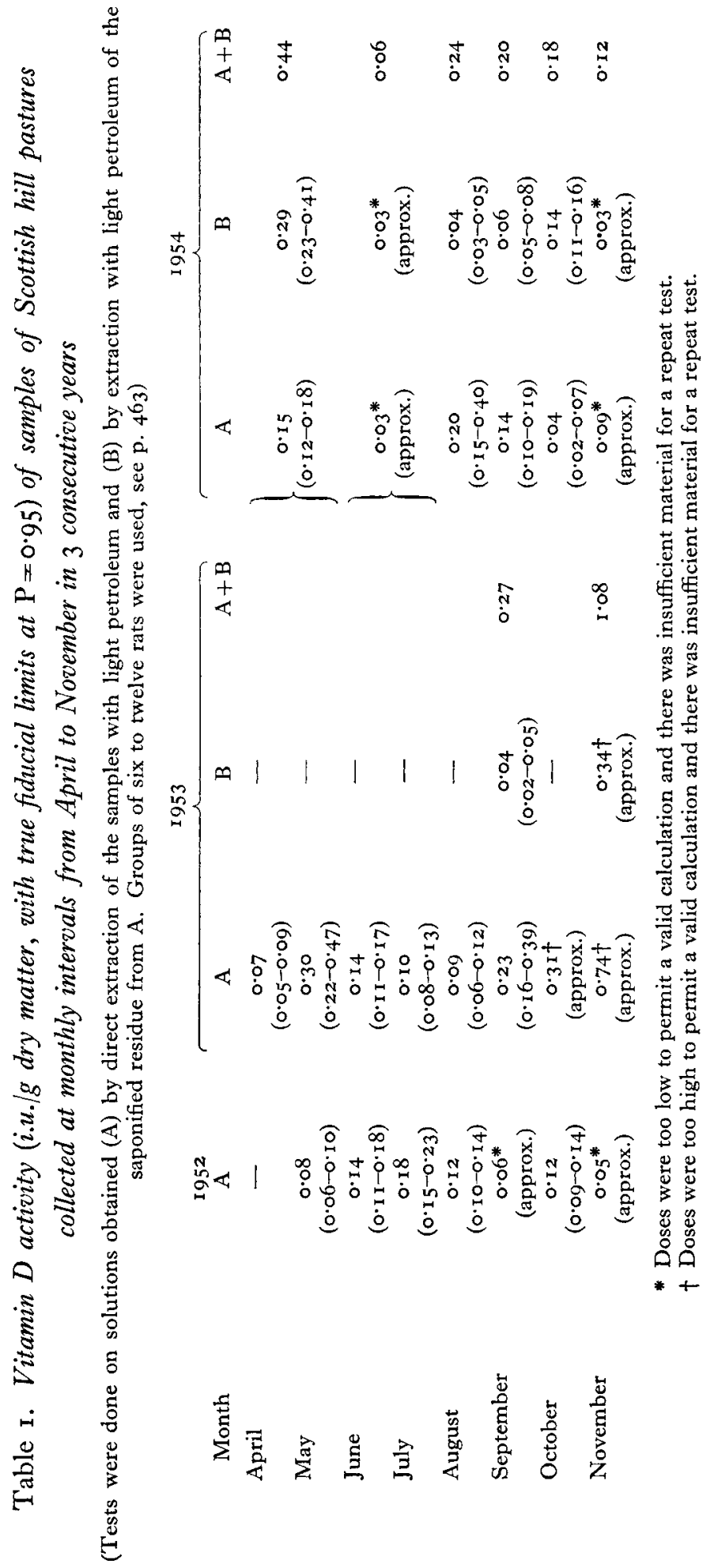


Table 2. Test of the adequacy of methods of extracting vitamin $D$ activity from pasture and hays

(i.u. vitamin $\mathrm{D} / \mathrm{g}$ air-dry material with true fiducial limits at $P=0.95$.

Groups of eight rats were used)

\begin{tabular}{|c|c|c|c|c|}
\hline \multirow{3}{*}{$\begin{array}{l}\text { Treatment of material } \\
\text { (a) Extracted with } \\
\text { light petroleum }\end{array}$} & \multicolumn{3}{|c|}{ I 955} & \multirow[b]{2}{*}{$\begin{array}{c}1956 \\
\text { 'special' hay* }\end{array}$} \\
\hline & Original sward & $\begin{array}{c}\text { Ground-cured } \\
\text { hay }\end{array}$ & Tripod hay & \\
\hline & $\begin{array}{c}0.04 \\
(0.02-0.05)\end{array}$ & $\begin{array}{c}0.23 \\
(0.17-0.37)\end{array}$ & $\begin{array}{c}0.12 \\
(0.09-0.15)\end{array}$ & $\begin{array}{c}0.53 \\
\left(0.34^{-1} \cdot 12\right)\end{array}$ \\
\hline $\begin{array}{l}\text { (b) Residue from }(a) \\
\text { saponified and ex- } \\
\text { tracted with light } \\
\text { petroleum }\end{array}$ & $\begin{array}{c}0.02 \\
(0.01-0.04)\end{array}$ & $\begin{array}{c}0.21 \\
(0.15-0.32)\end{array}$ & $\begin{array}{c}0.10 \\
(0.08-0.13)\end{array}$ & $\begin{array}{c}0.25 \\
(0 . \times 4-0.40)\end{array}$ \\
\hline (a) and $(b)$ combined & $\therefore \circ 6$ & 0.44 & 0.22 & 0.78 \\
\hline $\begin{array}{l}\text { (c) Saponified and ex- } \\
\text { tracted with light } \\
\text { petroleum }\end{array}$ & $\begin{array}{c}0.04 \\
(0.02-0.06)\end{array}$ & $\begin{array}{c}0.34 \\
(0.20-0.49) \\
\text { See p. } 464 .\end{array}$ & $\begin{array}{c}0.19 \\
(0.12-0.28)\end{array}$ & $\begin{array}{c}0.72 \\
(0.44-1 \cdot 23)\end{array}$ \\
\hline
\end{tabular}

DISCUSSION

Reports in the literature have indicated considerable individual variations in the vitamin D activities of different types of roughage (cf. Wallis, Smith \& Fishman, r949; Weits, $1953 b$, 1956). Our results for Scottish hill pasture show that variations between different samples of a single type of mixed herbage are also large. Wallis et al. (I949) and Weits (1956) have pointed out the probability that many factors besides exposure to ultraviolet light influence the vitamin $\mathrm{D}$ content of roughages.

In the past it was generally believed that the growing green plant contains little or no vitamin $\mathrm{D}$, and that the antirachitic activity of mixed herbage resides in the withered brown material, in which the provitamins had been activated by ultraviolet rays of the sun. There is evidence now, however, that green leaves may contain appreciable amounts of vitamin $\mathrm{D}$, although in lower concentration, sometimes markedly so, than does the withered brown material (Newlander, 1948; Weits, 1956). It has also been shown that vitamin $\mathrm{D}$ potency increases with the maturity of the pasture (Keener, 1954; Newlander \& Riddell, I952; Thomas \& Moore, 195I) and that the leafy portions of alfalfa hay are more active than the stem (Wallis, 1938). No one of these factors can be held to be entirely responsible for the variations in the potency of our Scottish hill pastures, as there was no consistent pattern in the results for the 3 years. It is probable that these along with other unknown influences combine to play their part.

It is clear from the work cited that winter feeds contribute more vitamin $\mathrm{D}$ to the diet of the cow than summer pasture. Feeding trials done at Shinfield some 20 years ago (Campion, Henry, Kon \& Mackintosh, I937) led to a similar conclusion. In those experiments two groups of cows were kept indoors in midsummer and given a normal winter ration or freshly cut good-quality grass. Two other groups were kept out-ofdoors; one was allowed to graze normally and the other was given the winter ration on bare ground. Both indoors and outdoors the cows on the winter ration had more 
Vol. 12

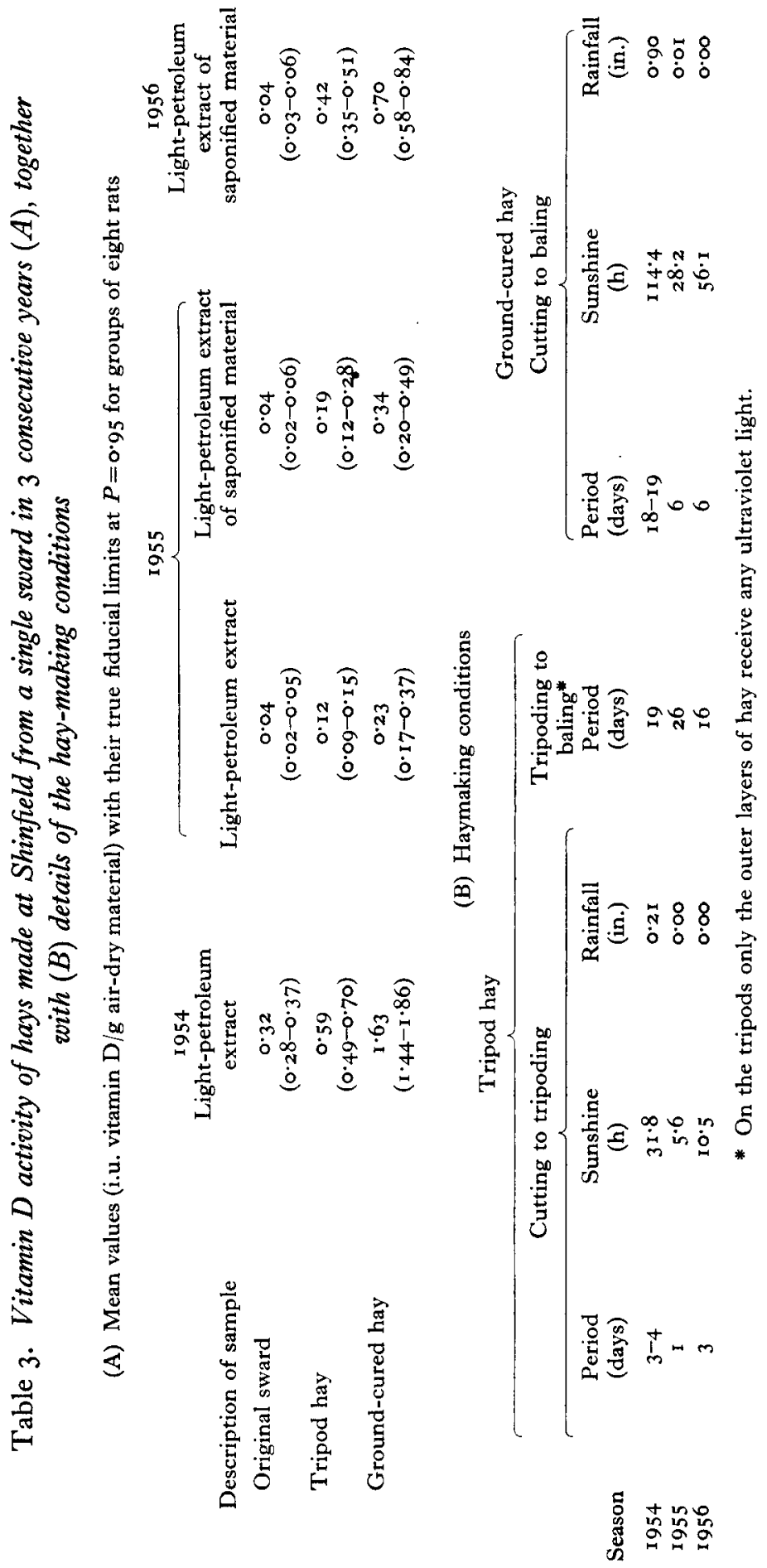


vitamin $\mathrm{D}$ in their milk than those receiving grass. With both types of feeding exposure to outdoor light caused a threefold increase in the potency of the milk fat.

Grant (I95 I, 1953) and Grant \& O'Hara (1957) in New Zealand and Weits (1952, 1954, 1956) in Holland have published evidence that points to the presence of an anti-vitamin $\mathrm{D}$ factor in roughages. Weits (1954, 1956) has consistently demonstrated the presence of varying amounts of this factor in artificially dried grasses and has found that it is present to a lesser extent, or not at all, in hay. The views are that this factor is carotene (Grant, I953; Grant \& O'Hara, 1957) or a factor associated with it (Weits, 1954, I956). It has been suggested (Keener, I954; Weits, 1954, 1956) that destruction of this factor during curing is in part responsible for the increased vitamin $\mathrm{D}$ potency of hays, compared with untreated pasture. Some support for this view may be deduced from the fact that carotene is destroyed during curing. Work on the problem of this anti-vitamin D factor is in progress at Shinfield; it is hoped to report on it later.

\section{SUMMARY}

I. The vitamin $\mathrm{D}$ activities of pastures and hays have been studied in two series of experiments. In the first the activities of samples of Scottish hill pasture from a single plot were determined monthly from April to November in 3 consecutive years. In the second series the activities of ground-cured and tripod hays made from a single sward at Shinfield were compared with that of the original sward. These experiments were repeated in 3 consecutive years.

2. Biological assays with rats were done on extracts of fat prepared by solvent extraction of the samples. Direct extraction with light petroleum did not remove all activity, but saponification of the samples with subsequent solvent extraction did within the limits of error of such tests.

3. The Scottish hill pastures contained $0.05^{-I} \cdot 08$ i.u. vitamin $\mathrm{D} / \mathrm{g}$ dry matter. No consistent trend could be detected in the 3 consecutive years.

4. Ground-cured and tripod hays made at Shinfield in 3 consecutive years contained, respectively, $0.34^{-1} \cdot 63$ and $0.19-0.59$ i.u. vitamin $\mathrm{D} / \mathrm{g}$ air-dry material compared with $0.04-0.32$ i.u. in the original sward.

5. The influence of factors such as exposure to ultraviolet light, stage of maturity, relative proportions of green and brown leaves and of a possible anti-vitamin D factor on the vitamin $\mathrm{D}$ activity of roughages is discussed. The results are insufficient for any decision as to whether one factor exerts more influence than another; it is concluded that all may be involved.

We are indebted to Miss M. V. Chapman, Mrs P. E. E. Todd and Dr J. Toothill for help with the biological assays and to Mrs P. Plack for help in preparing the extracts of the Shinfield samples.

\section{REFERENCES}

Campion, J. E., Henry, K. M., Kon, S. K. \& Mackintosh, J. (1937). Biochem. F. 31, 8 I.

Grant, A. B. (195I). Nature, Lond., 168, 789 .

Grant, A. B. (1953). Nature, Lond., 172, 627.

Grant, A. B. \& O'Hara, P. B. (1957). N.Z. F. Sci. Tech. 38A, 548. 
Henry, K. M. \& Thompson, S. Y. (1954). Milchwissenschaft, 9, I4.

Keener, H. A. (1954). F. Dairy Sci. 37, I 337.

Kon, S. K. \& Thompson, S. Y. (1957). Milchwissenschaft, 12, 166.

Murdoch, J. C., Foot, A. S., Hosking, Z. D., Line, C. \& Rowland, S. J. (1959). To be published.

Nelson, W. A. G. (1947). Analyst, 72, 200.

Newlander, J. A. (1948). F. Dairy Sci. 31, 455.

Newlander, J. A. \& Riddell, W. H. (1952). F. Anim. Sci. Ir, 4 I9.

Thomas, J. W. \& Moore, L. A. (1951). F. Dairy Sci. 34, 916.

Thompson, S. Y. (1959). To be published.

Wallis, G. C. (1938). F. agric. Res. 57, 393.

Wallis, G. C., Smith, C. A. \& Fishman, R. H. (1949). F. Dairy Sci. 32, 7 I 5.

Weits, J. (1952). Nature, Lond., r7o, 891.

Weits, J. (1953a). Private communication.

Weits, J. (1953b). Landbouwk. Tijdschr. 65, 592.

Weits, J. (1954). Neth. F. agric. Sci. 2, 32.

Weits, J. (1956). De antirachitische werking van nederlandse ruwvoeders in verband met het antagonisme tussen caroteen en vitamine $D$. Thesis: Wageningen.

\title{
Studies of the nutrition of the young calf
}

\author{
A comparison of starch, lactose, and hydrogenated palm oil, with \\ butterfat, in milk diets
}

\author{
By A. M. RAVEN AND K. L. ROBINSON \\ Chemical Research Division, Ministry of Agriculture for Northern Ireland and \\ Agricultural Chemistry Department, Queen's University, Belfast
}

(Received 26 fune 1958)

Calves are generally reared artificially, the normal farm practice being to feed on liquid diets from a bucket until the animal is from 8 to 12 weeks old. Whole milk is usually given for the first few weeks, but as soon as possible less expensive milk substitutes based on separated milk are introduced. The published results of numerous feeding trials show the superiority of whole milk during the first few weeks of the animal's life over any milk-substitute diet so far investigated. This superiority is not subsequently so well marked, as judged by live-weight gains and freedom from digestive upsets, but is nevertheless apparent.

The main difference between whole milk and most milk-substitute diets available to the farmer lies in the replacement of fat by lactose, glucose, sucrose and cereal starches, which suggests that the relatively poorer performance of very young calves on milk-substitute diets is brought about by the lower calorific value of the substitute diets and by the inability of such calves to digest certain carbohydrates.

In most investigations with calves comparing whole milk with milk-substitute diets, the basis of assessment has been that of live-weight gain. Therefore, little information is available as to the nutritional factors involved. The present investigation has been designed to study, by means of digestibility trials and nitrogen balances, the 